\title{
Critical Urban Cosmopolitanism and the Governance of Urban Diversity in European Cities
}

\begin{abstract}
This paper draws on the findings of a cross-national EU project named DIVERCITIES that analyses the relationships between narratives and meanings of the term 'diversity' and their influence on the governance and planning of European cities. It is widely argued that there is a growing dissonance between the policy narratives and agendas found in metropolitan cities and amongst national governments. The former are characterised as being more pragmatic, tolerant, and open in their approaches than the latter. In exploring these governance dynamics, the paper builds on the work of Delanty to argue for a methodological approach grounded in what he terms critical cosmopolitanism, or a focus on the dynamic interactions between global and local influences on governmentalities and policy priorities. Much of the writing on critical cosmopolitanism has focused on questions of identity. This paper expands the concept and assesses its applicability to understandings and interpretations of urban politics and governance, through the lens of diversity narratives and the ways in which they are 'fixed' to broader political projects by regimes in different contexts. It argues that a range of meanings are being attached to 'diversity'. In some instances the term acts as a focus for more progressive forms of intervention. In others, however, it is being used to justify divisive forms of growth politics or acts as a lightning rod for existing discontents. The paper concludes by reflecting on the impacts of recent anti-globalisation and immigration politics across Europe and the fragility of existing fixes and policy assumptions.
\end{abstract}

\section{Introduction}

'United in diversity' is the motto of the European Union, which aims to signify 'bow Europeans have come together, in the form of the EU, to work. for peace and prosperity, while at the same time being enriched by the continent's many different cultures, traditions and languages' (EUROPA, 2015: p.1). Such proclamations are one part of a broader assemblage of debates taking place across the continent in which the term 'diversity' has been used with growing frequency to both describe contemporary socio-demographic changes which have arisen as a result of international (and intra-European) migrations and to anchor discussions over governance reform and the direction of social and economic policy (Lädesmäki and Wagener, 2015). The extent of socio-cultural diversity is growing with official estimates stating that $9.9 \%$ of the EU's population now consists of citizens born in a country different to the one in which they reside. Approximately two-thirds of these were born outside the EU, a proportion that is increasing as birth rates fall and migration increases (Eurostat, 2016: p.1). In the wake of these demographic shifts, policymakers, it is widely argued, face growing challenges in catering for the needs of diverse populations whilst ensuring that broader policy objectives, such as the promotion of economic growth and social cohesion, continue to be met (see Tasan-Kok, et al., 2013). New geographies are emerging in which major cities across Europe are acting as the territorial containers in which the majority of recent migrants, both legal and illegal, now live. The language of 'arrival cities' and 'reception places' have taken on a growing significance (see Saunders, 2010). 
One consequence of the increasingly intensive use of the term diversity in academic and policy discourses, however, is that it has turned it into something of a chaotic concept (cf. Sayer, 1997). It is used inter-changeably to describe ethnic, class, and lifestyle distinctions between different groups and has become synonymous in the Anglophone world with multi-culturalism, cosmopolitanism, and pluralism. In some countries diversity is elided with neo-liberal programmes that promote the 'end of welfare' as the 'logical consequence' of the assumption that 'migration is making contemporary European societies more diverse; and diversity undermines the sentiments of social solidarity that have sustained welfare states' (Clarke and Newman, 2012: p.94). At the same time, other commentators point to the presence of growing cultural and ethnic diversity as the basis for social disorder and fragmentation across Europe (see Goodhart, 2004). The European Elections of 2014 are presented as evidence of a widespread shift in popular discontent and a rejection of the openly pluralist, cosmopolitan politics of the 1990s and 2000s (see The New Statesman, 2014). Even mainstream political leaders such as Angela Merkel claim that the period of pluralist and multi-cultural politics is 'dead' and that social policy should focus more on integration in the midst of diverse societies.

It is in this broader context that the paper reports on the findings of a major EU research project on the governance of urban diversity that aims to explore some of the key policy responses taking shape in cities across the continent and the ways in which the term is being connected to a number of geographically differentiated political projects and agendas ${ }^{1}$. In order to bring greater clarity and analytical framing to the term, the paper explores the inter-relationships between 'diversity' narratives in urban and spatial policy frameworks and conceptions of cosmopolitanism. The discussion builds on the recent work of Delanty (2013) and his call for research to develop an approach grounded in 'critical cosmopolitanism', or to examine the ways in which social phenomena and processes of governance are created out of the encounter between local and global influences and trends. These encounters, Delanty argues, are shaped by diachronic and synchronic interactions that differ markedly between different contexts and represent reflexive and incomplete processes, or works in progress. Much of the writing on cosmopolitanism has focused on questions of identity and diverse living. In this paper the focus, instead, is on the institutionalisation of governance agendas and the value of cosmopolitanism as an analytical frame to explain and describe contemporary political processes.

The paper develops this argument further and calls for an approach grounded in critical urban cosmopolitanism or a form of interrogation that examines the specificities associated with the urban dimensions of cosmopolitanism and framings of diversity. It uses a range of case studies to distil key trends in the politicisation of the term and the dynamic but highly contextualized and reflexive interactions between global and local urban processes that are now emerging and with what effects on governmentalities and policy framings. It identifies the core interests or regimes that propagate diversity narratives and their impacts on urban and spatial policy practices and outcomes. It also highlights the form and character of the diversity fixes and policy resolutions that are made in cities and their fragility in the wake of shifting political, economic, and social conditions. These fixes and resolutions emerge through what Delanty terms 'structure-forming

\footnotetext{
${ }^{1}$ Named DIVERCITIES, see: $\mathrm{http}: / /$ www.urbandivercities.eu/
} 
effects' relating to diverse histories, governance systems, and cultural meanings attached to social and political discourses. Such an approach, the paper argues, is increasingly important in conceptual and policy-related debates given the primary importance of European cities as reception places for diverse groups and recent events across the EU including the so-called migration crisis, ISIS terror attacks, and the UK's Brexit vote (see Žižek, 2016). They are the locations in and through which the tensions between cosmopolitan and territorial relationships are at their most intense and in which resolutions to these tensions can be found. The paper begin by discussing broader debates over the meanings ascribed to the terms diversity and cosmopolitanism within the EU and beyond before turning to some of the core findings of our research and what these tell us about emerging geographies of the term.

\section{Cosmopolitanism and the Rise of Diversity Narratives in the EU}

\section{Growing Diversity and Critical Urban Cosmopolitanism}

In cities and nation-states across the EU there are intense political debates underway over the relationships between different forms of identity, the internationalisation of economic ownership and control, and the territorial organisation of political powers. For Beck and Grandes (2007) national identities and policy-making frameworks are being eroded by the expansion of EU institutions and legal frameworks, often based on principles of rights-based cosmopolitanism. Contemporary modernity, it is claimed, has brought about such significant changes in the ordering of political imaginations and spaces that we have to question the extent to which 'politics and the state have become zombies - dead long ago but still haunting people's minds' (Beck, 2000: p.80). What is taking place in the EU is a reflection, for some writers, of the ways in which cosmopolitan modes of governance and institutionalisation are now replacing the nationstate building that characterised earlier phases of modernity (see Held, 2010). Trans-national discourses, problems, and agendas are, it is claimed, being identified and translated into new programmes of political action. In methodological terms, research on contemporary governance should, therefore, suspend 'the assumption of the nation-state... [to] make the empirical investigation of local-global phenomena possible’ (Beck and Sznaider, 2006: p.9).

However, this view of creeping cosmopolitanism does not translate, in a simple way, into situated policy responses. As Delanty (2013) argues, the notion that the existence of the EU and a broader 'European project' is leading to new forms post-national political narratives underplays the critically constructed forms of institutionalised politics that are emerging. These, he claims, are shaped by the complex interplay of historical and cultural plurality across Europe, EU projects of supra-national integration, and broader, and increasingly difficult to control processes of capitalist globalisation. Assumptions of an inexorable shift towards a post-national future are 'at best incomplete and uncertain' as the 'relation between the EU and nations is a reflexive one as opposed to being a hierarchical one' (p.251). The EU's complex and principally bureaucratic institutional arrangements thus sit 'alongside national identities to varying degrees of tension' (p.254) so that 'from the perspectives of a critical cosmopolitanism the category of the nation should be seen in terms of a conflicting constellation of cultural and political forces' with postnationalist subjectivities and political agendas, such as those associated with increasing diversity 'formed out of the interaction of multiple publics and chiefly realised through nations' (p.262). 
For Delanty a more fruitful and analytically robust way of approaching political trends is to explore reflexive forms of what he terms critical cosmopolitanism or 'the identification of how normative principles are interpreted and appropriated by social actors and the processes and mechanisms by which these enter into institutional forms' (p.269). State institutions, with territorial jurisdictions, are having to adapt policy-making processes, structures, and outcomes to the growing presence of populations that have direct relations and networks beyond their immediate territories and spheres of influence (see Robinson, 2013; Schiller and Caglar, 2009). What, therefore, take on greater significance are the institutionalised governance programmes in and through which 'the logic of translation has extended beyond the simple belief that everything can be translated to the recognition that every culture can translate itself and others....It is the nature of such translations that the very terms of the translation is altered in the process of translation and something new is created' (Delanty, 2006: p.43).

\section{Diversity Fixities and Resolutions: Governing Diversity in an Era of Cosmopolitanism}

The term diversity has featured strongly in urban and regional policy debates across Europe in recent decades and has both reflected and reproduced broader framings of cosmopolitanism (see Arapoglou, 2012). As noted above, it has become a rather chaotic concept, prone to multiple interpretations and deployed to meet a range of diverse and sometimes contradictory agendas. Debates over diversity's core political meanings have been fuelled by broader tensions between those who present it primarily as a 'cultural/semiotic' construct, concerned with the presence of multiple identities and cultural rights, and others who see it in 'economic/material' terms, or through the distinctions between collective class interests (see Fincher and Iveson, 2012). Whilst this simple binary distinction is sometimes over-drawn in critical writings on diversity it has influenced those aspects of the term have been politicised in urban contexts and how.

As Keith (2005) argues, it is in cities that the greatest juxtapositions of different groups are to be found in Europe. Urban policy-makers, state institutions, and citizens are confronted with the day-to-day realities of providing services to, and developing participation amongst, an increasingly broad population base, whilst also maintaining political legitimacy, implementing (national) programmes of (welfare) reform, and promoting economic growth. There has also been a growing interest amongst policy-makers in how organisations can 'contain' and 'make use of diversity for broader policy orthodoxies and priorities (see Clarke and Newman, 2012). We might, therefore, expect specific forms of critical urban cosmopolitanism to emerge between broader epochal, diachronic changes and the synchronic politics of specific contexts and how they are shaped by institutionalized and contextualised understandings of diversity (see Delanty, 2012).

Writings in economic geography have been particularly influential in providing intellectual justification for specific forms of resolution/fixity with their emphasis on the importance and power of resurgent urban economies and their populations. As Nathan (2015) shows, a diversity of workers and 'tolerant' and open forms of urban politics are presented as necessary ingredients for contemporary forms of urban growth as policy agendas echo the economic orthodoxies. The World Economic Forum (2015) even go as far as to highlight the importance of 'diversity dividends' in cities and places that are more diverse and possess a broader range of creative and 
entrepreneurial workers (see Syrett and Sepulveda, 2012) ${ }^{2}$. Such proclamations provide a set of clear prescriptions for urban and social policy and see higher levels of migration and sociocultural diversity as a precondition for economic advantage. Despite a range of evidence showing that economic growth is a consequence of a much broader range of dynamics and influences (see Martin, 2015) and that the types of growth supported by enhanced diversity generate employment that can threaten the terms and conditions and poorer workers, the political and economic arguments for the promotion of 'more diversity' have become a powerful and influential orthodoxy.

Under certain conditions, the emergence of such orthodoxies points to the strength of locallyconstituted economic and political elites or what might be termed diversity regimes. These regimes may consist of well-organised networks and constellations of actors and institutions that seek to fix narratives and framings of diversity in order to pursue selective political agendas. These fixes are created reflexively and often involve a conflation of economic and social policy priorities and objectives in the pursuit of establishing 'creative' cities. For city-based regimes, the promotion of 'positive agendas' focussed on the 'benefits' of diversity can fulfil a number of roles, depending on the specific urban contexts in which they are mobilised and put into practice. In major global cities, there may be a strong convergence in the agendas of public and private sector organisations and the establishment of relatively strong regimes. Diversity, within such contexts, is often elided with the attraction of workers in a range of sectors including highperforming, knowledge-based firms and relatively low-skilled service sector companies and public organisations, whose work is necessary to the functioning of an urban society. The presence of socio-cultural diversity can also be converted into a marketable commodity to attract foreign investment and mega-events. In other contexts, regimes may form to promote an image of urban diversity to meet very different ends, such as an imagined mark of recognition of a city's 'modernity' or true 'accession status' to an imagined set of (western) European ideals.

Many EU governments have adopted fixes that draw on a more restrictive vocabulary of postmulticulturalism, with the presence of 'too much diversity' seen a potentially divisive influence and source of social conflict. This post-multiculturalist approach sees attempts to recognise diversity as undermining a collective sense of nationally (and sometimes ethnically) based identity and collective endeavour. Rather than accepting the premise that higher levels of social diversity leads to greater tolerance and a fusion of horizons and outlooks, the emphasis is on the similarities rather than the differences that exist within nation-states (Delanty, 2013). In some instances this is being driven by real or imagined threats to social order, such as religious extremism, or the insecurities caused by growing social inequalities and economic crisis. This emphasis on territorially-defined assimilation reinforces bounded views. Recent debates over the migrant crisis have been characterised by crude simplifications between dysfunctional Southern European states on the borders of the EU, the overwhelmingly 'nationalistic' views of Eastern European societies and governments, and the well-organised but over-burdened Northern European countries (see The Economist, 2016a).

\footnotetext{
${ }^{2}$ World business leaders in Davos in 2015 lauded the 'diversity dividends' that accrue from diverse labour markets and the wider pool of skills and talent that they bring (see Peston, 2015).
} 
It is in this wider context that the paper now draws on the findings of a comparative EU project that examines the principal meanings and technologies that are being ascribed to the term 'diversity' within urban and spatial policy frameworks in selected cities across the EU and the specific contextualisations through which critical urban cosmopolitan agendas are being politicised and institutionalised. The cities were selected through a purposive sampling framework that categorised them as: a) globally-oriented with diverse populations and large numbers of migrants (London, Milan, and Paris); b) Eastern European cities that have experienced recent accession to the EU (Budapest, Tallinn, and Warsaw); and c) medium-sized cities in European terms in which political debates over in-migration and its impacts on social 'cohesion' and economic development have featured particularly strongly in urban policy debates (Athens, Antwerp, Copenhagen, and Rotterdam). Figure 1 shows the comparative statistics of each city's total population and the percentage of defined ethnic groups. They indicate that in most cases a fifth of residents or more are described, or describe themselves, as having an ethnicity that is different to the (imagined) host country.

\section{INSERT FIGURE 1 HERE}

The discussion will demonstrate the diverse form and character of diversity narratives and cosmopolitanism that are emerging in different contexts and highlights some of the conditions that generate these differences. It analyses the core tensions that exist between: national and cosmopolitan forms of governmentality; territorially-bounded claims to citizenship(s) versus universal claims; processes of economic restructuring and development; and institutionalised imaginations of social cohesion and ordered urbanism. In each case research teams examined dominant narratives of diversity at both national and city levels and the influence that these narratives have had on the setting of policy priorities, objectives, and outcomes. Identical indepth interviews were carried out with key actors, both governmental and non-governmental. These were triangulated with in-depth textual and discourse analyses of core documents, strategies, and development plans. An overview of the findings will be used to document a widespread shift towards new imaginaries in which it has become increasingly common for city authorities and elites to claim that their cities have particular and 'different' needs vis-à-vis national or EU concerns.

These 'urban diversity fixes' are embedded into a series of diverse and highly contested political projects. In some cases, particularly in smaller countries, this has encouraged the formation of more openly 'cosmopolitan' agendas at national and regional levels in direct response to the experiences of major cities. In others, however, cities have also acted as crucibles for the formation of more critical agendas towards diversity and migration and there has been a backlash against attempts to fix meanings by elite political and economic regimes, the EU, and other interests.

\section{Critical Urban Cosmopolitanism and the Emerging Geography of Diversity Politics in the EU}


In this section the paper draws on evidence taken from research reports on each of the project's case study cities and explores some of the diversity fixes that have been mobilised by governance regimes and their influences on policy agendas. It identifies two principal forms of critical urban cosmopolitanism that have emerged to differing degrees and in some instances simultaneously: (i) the attempt to create consensual and pragmatic governance fixes that promote positive and instrumental visions of diversity and reinforce and reproduce many of the policy orthodoxies propagated by those who promote a view of global, post-national cosmopolitanism and economic growth; and (ii) the limited reach of such fixes and the conditions under which references to 'diversity' act as a lightning-rod for broader discontents and the critical rejection of global visions of cosmopolitanism. The discussion draws on approaches grounded in critical cosmopolitanism to explore the reflexive and historically inscribed forms of spatial and urban policy that are emerging and the wider implications of change for contemporary urban politics.

\section{(i) Diversity fixes and pragmatic approaches to city governance}

One feature of the governance agendas found across our case studies was a widespread recognition that urban policies towards 'diversity' have had to adopt 'pragmatic' approaches to governance. New policy fixes have been mobilised and enacted that aim to make 'best use' of contemporary urban cosmopolitanism and 'embrace' the opportunities opened up by the presence of socio-cultural diversity. In echoes of the language of resurgent urbanism and the New Economic Geography, discussed above, the politics of 'urban pragmatism' seeks to convert diversity into an instrumental tool to foster globally-oriented economic growth, allied to a politics of social cohesion and cultural dynamism. Agendas focus on the benefits of diversity for economic competitiveness through three principal causal relationships: i) that the presence of higher levels of social and cultural diversity encourages the in-migration of 'talented' and 'creative' class workers; ii) that curated and commodified forms of diversity facilitate new forms of place branding and can boost inward investment; and iii) that diversity encourages the establishment of a 'creative atmosphere' in cities that allows new forms of entrepreneurialism to flourish. Across the cases there is a clear agenda of 'urban exceptionalism', or the argument that major cities have 'different' economic potentials and require pragmatic and non-ideological policy interventions that take account of their socio-cultural and economic conditions and priorities.

London represents the most illuminating example of this trend and the city in which the critical cosmopolitan interactions between global and local processes are having a significant impact on development trajectories and urban policy agendas. Since the early 2000 s powerful regimes have sought to curate the city as a cosmopolitan centre or a 'world in one city'. There is an explicit emphasis on making London into a 'global talent hub' with an available pool of skilled workers, the presence of a pro-business growth politics, and an expansion in the availability of housing for key workers. The former London Mayor even called for a new Visa Category for those with 'Exceptional Talent' to be allowed access to London in order to provide a 'clear message to the elite of Silicon Valley or the fashionistas of Beijing that London is the place they should come to 
develop ideas, building new businesses and be part of an 'epicentre' for global talent' (Johnson ${ }^{3}$, quoted in Warrell and Pickford, 2013: p.1). The dominant narratives within policy frameworks and strategies openly celebrate the presence of diversity and present the city's politics as being 'different' and more 'in-touch' with the everyday realities of contemporary urban living than some of the more negative agendas espoused by national policy-makers.

For smaller or medium-sized cities the presence and curation of 'diversity' branding has also been used by elite interests to support broader ambitions to convert their cities important economic nodes within imagined urban hierarchies. Specific readings of cosmopolitanism and diversity are fixed in ways that emulate those of iconic examples, such as London. In such cases diversity policies are used to legitimate potentially controversial and divisive economic reforms that seek to promote more globally-oriented modes of speculative and image-focussed development. In cases such as Milan the marketing of socio-cultural diversity forms an important component of attempts to establish a 'smart city agenda', that is internationally competitive and able to attract the best workers and foreign companies. As Barberis et al. (2014) note, diversity policies are 'aimed at supporting groups (e.g. youth) that may produce a positive return for the city: attracting young professionals (researchers and fashion professionals among the most mentioned) can boost competitiveness; revitalizing public properties (where new initiatives are encouraged to locate) can improve dilapidated neighbourhoods' (p22). In other cases, such as Athens, regimes have adopted similar language and economic development agendas influenced by creative class policy prescriptions. As Maloutas et al. (2014) show development strategies in the city have increasingly focused on 'investment in knowledge-intensive sectors and public real estate assets, cultural and urban tourism and education in classical studies, shipping and tourism'.

What such examples highlight are the specific policy resolutions that take place in cities and the ways in which potential tensions and disagreements over the direction of urban policies can be channeled into commodified forms of cosmopolitanism and economically-oriented agendas, underpinned by powerful interests. These resolutions are reinforced by proclamations of urban exceptionalism and the argument that cities need 'bespoke' forms of policy that reflect their 'progressive' cosmopolitan politics and their economic role(s) as centres of globally-oriented economic growth and 'success'. Diversity politics has become bound-up with fiercely contested arguments over the distribution of political power within governance systems and the extent to which city and local authorities possess sufficient autonomy and resources to set out their own priorities and agendas. In some cases the presence of diversity is used, for instance, to argue for greater devolution of powers and responsibilities to the city scale in order to facilitate better policy-making that is more in-touch with a [diverse] city's needs. Such narratives and fixes are not only promoted by government interests and actors but by powerful regimes. Business groups, in particular, have been amongst the strongest supporters of more open and tolerant approaches to migration as part of an explicit talent-building agenda. More restrictive policies and attitudes to diversity are presented as a threat to city competitiveness. In London for instance it is influential groups such as London First who act as vociferous exponents of greater openness to in-migrants and present greater diversity as a core factor of production for a variety

\footnotetext{
${ }^{3}$ The former Mayor, Boris Johnson, is a Conservative Party politician who was elected in 2008 and re-elected in 2012.
} 
of successful economic sectors. Business voices in other cities have mainly been articulated through Chambers of Commerce, and other more traditional representative groups, but even here they have been consistently in favour of broader cosmopolitan visions of, and more open policies towards, socio-cultural diversity.

Dominant cities have a particularly strong and sometimes disproportionate influence on national social and economic policy priorities and arrangements. Copenhagen, for instance, is presented in urban policy narratives as Denmark's 'only real metropolis', with demographic and economic diversity that make it unique in the Danish context (see Andersen et. al., 2014). City development strategies and policy respondents consistently promote the idea that Copenhagen's competitiveness is dependent on a pragmatic and economically driven pro-migration policy, allied to a set of social policy interventions that enable poorer migrants to 'integrate' more effectively into Danish society and to tackle the socio-economic inequalities that are seen to lie at the heart of existing divisions. Whilst, this has been allied to a stronger approach to migrant participation and responsibilisation, the city is also curated by local regimes as 'the most inclusive metropolis in Europe, in marked contrast to Danish national policy that is becoming more rhetorically hostile to migration. We find similar trends in other capital cities in which there have been active and on-going attempts to use narratives of diversity as a discursive technology to emphasise the differences that exist between their approaches and those of the national government and to influence the latter to adapt and meet the needs of the former. In Tallinn, for instance, as Tammaru et al. (2014) have shown 'a more pluralist discourse can be found at the city level...the minority voice is stronger and better represented in Tallinn where they form a higher share compared to the whole country' (p.4).

However, despite this widespread narrative of 'urban' openness to socio-cultural diversity, the growing conjunction of economic and social policy objectives found within these 'pragmatic' agendas is creating new ambiguities. The focus is moving towards an implicit (and sometimes explicit) set of divisions between 'good' and 'bad' migrants and optimal 'types' of diversity. These distinctions are becoming institutionalised in the synchronic practices of city politics and the expansion of economic justifications for social policy arrangements. There is a growing selectivity in characterisations of the costs and benefits of diversity and those types of population groups that 'contribute' to the economic well-being of a city and those which do not. There has been a broader shift in dominant descriptions towards what Ahmed (2013) terms 'willing' and 'unwilling' migrants, or those whose presence has become an objective of broader accumulation strategies and those who are not.

In Rotterdam, for instance, despite the positive and pragmatic narratives used in urban policy agendas there has been a growing emphasis on the encouragement of what local policy-makers term 'fast diversity' in which more creative and talented migrants are attracted to the city in distinction to the 'slow' diversity associated with poorer migrants and guest-workers (see Tersteeg, et al., 2014). The former become a self-sufficient and much sought-after priority. The latter are presented as a policy 'problem' whose presence is seen as an impediment to the city's development ambitions. There are also echoes of these trends in major cities such as London that ostensibly promote themselves as role models of pluralism and tolerance. The former Mayor of London, for instance, summarises changing narratives in claiming that London would 
benefit from an 'immigration policy to attract the brightest and the best to London but keep out those who bave no intention of making a contribution' (Johnson, 2012: p.51). The emphasis on 'talent' is short-hand for a particular class of migrant and in this sense policy objectives are falling into line with longer running policy narratives that focus on 'key' or 'essential' workers at the expense of those subjects who fall outside of such categories. City regimes in almost all of our cases have adopted so-called 'support and demand' policies in which welfare support is given to a wider range of diverse groups but on condition that they take greater responsibility for their own circumstances and welfare (see also Plüss and Schenkel, 2014).

In such contexts greater diversity and cosmopolitanism are being re-imagined and elided with neo-liberal welfare reforms. They are part of a general move away from a policy concern with equality of outcomes to a focus on ensuring equality of opportunities for individuals, with diversity redefined as a source of difference that necessitates a break-down of universal welfare policies. Even in more ostensibly 'progressive' narratives, there is a tendency for policy to reflect national and EU imperatives to 'celebrate cultural diversity' rather than seeking 'to establish economic equality' (Michaels, 2010: p.12). Attention is shifted away from some of the primary causes of inequality such as neo-liberal capitalism, labour market changes, discrimination, and market-led welfare reforms. This has been compounded by austerity policies and welfare cuts in a number of our cases.

Despite this broader trend, pre-existing modes and legacies of governance continue to exert a powerful hold over the ways in which global and local influences interact in specific urban settings. Cities such as Rotterdam and Copenhagen, for example, are becoming centres for property investment but both possess relatively strong public planning systems that draw directly on the language of social diversity to justify the construction of housing that is mixed in use and tenure. In other words, where strong, welfare traditions have been in place for decades, planning arrangements retain greater influence on the shaping of urban environments and can embed principles of cosmopolitan diversity into their policy priorities and outcomes. So, whilst it is possible to identify a broader trend towards the building of new urban environments that are geared up to the needs of creative groups, the form and character of such developments and the understandings of diversity that they embody are markedly different from the gentrifying agendas found in cities such as London.

A focus on critical urban cosmopolitanism has particular resonance in explaining the form of diversity narratives in Eastern Europe in which debates over the pragmatics of being positive towards socio-cultural 'diversity' and broader readings of pervasive 'globalisation' draw directly on (re)combinations of earlier histories and the influences of EU accession. This, in part, derives from a legacy of state socialism and the forced transfers of ethnic groups in the aftermath of World War Two, which as Lowe (2013) argues left Eastern Europe 'far less multicultural than it had been at any time in modern history' (p.248). However, it is also a reflection of the ways in which political projects have emerged that seek to establish specific paths of modernisation and reform.

In cities such as Warsaw, Korcelli-Olejniczak, et al. (2014) show that regimes in the city would like to see a more positive approach to diversity to support inward investment and creative city 
agendas. As they argue, 'diversity is an issue directly and indirectly called upon by policy-makers, urban activists, the participating public (residents) as well as other organizations and institutions dealing with urban and social development; it is understood as the result of an evolving process of social awareness, a consequence of globalization and metropolisation' (p.11). Urban leaders, businesses, and other actors explicitly argue that it is not only the presence of diverse socio-cultural groups that fuels growth but also the common 'attitudes' that exist within the population towards migrant groups of different kinds, many of whom have been drawn to the city in the 2000s but have remained outside of the formal, legal system. The incorporation of such citizens into a more formal and diverse social order is a key objective of recent policies. In line with other accession states, diversity narratives have featured 'within other notions and concepts, such as 'strive for equality of opportunities', 'disparities', 'inequalities', 'common good' 'equal treatment', 'diversification of space and society', 'discrimination' (p.11). Similarly in Budapest, there has been a concerted effort from city authorities to promote forms of social diversity that will fuel economic competitiveness to make the best of diversity, in line with formal national policy agendas. Fabula et al. (2014) demonstrate that the country's 'National Migration Strategy for the 2014-2020 period...simplifies residency schemes and promotes legal migration, especially of those arriving with 'economic purpose' e.g. investors, skilled labour' (p.9). Within Budapest, the Budapest 2030 strategy adopts the language of inclusion and explicitly promotes diversity as a source of economic dynamism and creativity.

To summarise, in a number of our cities, particularly those that possess large populations of foreign migrants and are looking to establish themselves as powerful economic centres, processes of critical urban cosmopolitanism have been manifest as a self-proclaimed pragmatism. The social and cultural diversity of urban populations has been increasingly commodified and presented as a resource that underpins contemporary economic development priorities. What is emerging is a set of dynamic re-combinations of global and local trends, influences, and processes in diverse urban environments in which longer term diachronic changes and imaginations of 'successful' global cities are being woven into synchronic policy narratives and objectives to form new agendas. However, these re-combinations do not create uniform outcomes and within these cases differentials in political systems, central-local arrangements, and diverse histories and development trajectories have influenced framings of diversity. Alongside cities in which sociocultural diversity is 'celebrated' our research also uncovered cities in which the term had either been ignored, not featured prominently in urban political debates, or had acted as a lightning-rod for broader political discontents and it is to these that the discussion now turns.

Diversity as a lightning rod for conflicts and new tensions

Whilst much of the Anglophone literature views discussions of diversity through a multiculturalist/post-multiculturalist frame of reference, the reality in many European cities is that narratives emerge and evolve in response to a wide range of influences and political objectives. In Paris, for instance, the term 'diversity' is dissonant with long-standing Republican values and traditional forms of welfare provision. The Republican model does not formally recognise diversity, and prohibits positive 'discrimination' in any terms other than economic 
disadvantage (See Escafré-Dublet, et al. 2014). ${ }^{4}$ In other cases strong forms of post-multicultural politics and strategies towards diversity have emerged in the wake of economic crisis and a growing perception that there has been 'too much' recent in-migration of groups that are both culturally distinct and economically less privileged. Maloutas et al. (2014) show that in Athens, integration policy has become embedded in broader discussions over urban order and security and state capacities. Similarly in Milan, Barberis et al. (2014) show that despite efforts to focus on a pragmatic case for diversity in policy frameworks, there is simultaneous trend in which narratives of diversity are grounded neither in traditional assimilationist or multicultural models but 'contradictorily are aimed both and recognizing diversity and to limit it in favour of social cohesion' (p.34).

In some locations diversity narratives combine with conflictual political environments, leading to very different outcomes. In Antwerp growing socio-cultural diversity has acted as a lightning rod for broader social tensions and political discontents. In recent years, the urban scale has been used to promote particularly assertive forms of Flemish nationalism and the rise of what Saeys $e t$ al. (2014) term a 'post-multicultural politics'. Nationalists have dominated the city's politics since the late 1980s following the electoral success of the Flemish far-right Vlaams Blok party who openly rejected social policies that discriminate in favour of minority groups. The far-right never came to power and was condemned in court for inciting racism. In the 2012 municipal elections, it lost many of its voters to a newly established right-wing nationalist party (N-VA) that is currently in power and has pursued a fiercely critical agenda towards diversity and pluralism. Much of the rhetoric of diversity has been selectively anti-Muslim, with relatively little attention given to problems of integration that result from the presence of many native born Dutch or other 'white' residents. The emphasis, instead, has been on the imagined threats that demographic changes are having on urban order in the city and an approach that claims that 'the city only belongs to the people who make an effort to belong to it (p.17). Recent City Plans have, as Saeys et al. (2014) argue, deliberately broadened definitions of diversity to include a much wider range of groups than cultural and/or ethnic groups. Instead of this representing a form of greater inclusively, the political logic behind this move is to dilute the potentially transformative elements contained within its language and reduce its potential for acting as the basis for more inclusive and migrant-focussed agendas. This is part of a wider trend in many cities, but in Antwerp it has been integrated and institutionalised into other attempts to shift the focus of diversity away from exclusion and the needs of in-migrants ${ }^{5}$.

\footnotetext{
${ }^{4}$ As Escafré-Dublet, et al. (2014) note the 1958 Constitution guarantees the equal treatment of individuals regardless of their ethnic, religious or racial belonging. Consequently, 'diversity is regarded as taboo or too broad by French governmental and nongovernmental actors...not least the fact it is illegal to identify particular sub-groups of the French population in official statistics and thus public policy targeting' (p.27). The French Republican Constitution is founded on the principles of secularism or laïcité making it very difficult for urban policy-makers to actively promote 'diversity' or the principles associated with transnational cosmopolitanism. The attacks of November 2015 have further heightened tensions in the city over identities and material inequalities, with any formal recognition of cosmopolitanism presented as a threat to the structures of governance.

${ }^{5}$ At the time of writing, the violent events that took place in Brussels in March 2016 and their direct connection to marginalised social groups have further heightened these tensions and political antagonisms.
} 
In former Communist cities contemporary debates on diversity have also re-kindled pre-existing conflicts over the legacies of communism and the contentious issues of national identity and citizenship raised by mass-transfers of populations during the 1950s and 1960s. As Fabula et al. (2014) note: 'during state socialism any kind of difference (class, religion, language etc.) was denied, equality and assimilation were forced as part of the official state ideology on the road towards a classless society' (p.29). With the fall of the Berlin Wall accession countries were required to engage with EU policy orthodoxies such as social cohesion, exclusion, and diversity that reflected policy concerns and agendas in many Western European countries. The process of accession into an existing, dominant set of institutionalised agendas and priorities reflects Delanty's (2013: p.11) observation that the EU posits 'political unity' in its formal frameworks and thus 'relegate[s] culture to the regional and national levels'. This has had significant implications for incorporate states such as Estonia, in which the position of Russian-speaking ethnic communities vis-à-vis other groups has become a pressing concern in a context where such identities are also connected to socio-economic inequalities (see Tammaru et al., 2014).

Cosmopolitanism and diversity are also shaped by formal public policy frameworks and their translation into local contexts. Being 'seen to be diverse' becomes a badge of wider recognition and evidence of 'integration' into an imagined European project of inclusivity and harmony. This is institutionalised in Accession Agreements that require Member States to implement social and economic urban programmes and human rights legislation. In cities such as Budapest city policy-makers seek to demonstrate that 'tolerance' and 'plural' social agendas now represent core components of their urban and social policy agendas. In the former, as Fabula et al. (2014) note, 'since the EU accession (2004), one of the most important tasks has been the continuous harmonisation of the minority and migration legislation with the common standards' (p.9). Specific urban programmes, such as URBACT, have created new forms of diversity-focussed interventions and promote a transnational concept of universal, cosmopolitan rights, for all EU residents EU accession has also brought about, at the very least, rhetorical shifts in social policy narratives and required elites or regimes to use the centralised language of diversity and inclusion. In Athens, for example, there is evidence that in a context of austerity that 'urban policies are fully aligned with the priorities of the EU. But at the same time, the adoption of EU political lines by the regional and municipal authorities remains often superficial. The repetition of EU political rhetoric becomes a technical prerequisite for the use of EU funds in the implementation of specific projects...this has a determinative impact (Maloutas et al., 2014: p.15). Similar trends took place in Estonia, which joined the EU in 2004 and in which 'both the pressure from EU during the accession talks as well as 'normalisation' of the society after the dismption of the 1990s brought increasing attention to the need for a better integration of ethnic minorities' (Tammaru et al., 2014: p.9).

The presence of strong and well-organised anti-migrant groups has also been influential in shaping formal city-level responses to growing diversity. In Budapest, for instance, a positive and inclusive rhetoric on the benefits and strengths of diversity has been adopted by leading politicians and other interests to distance formal policy frameworks from those of more extreme nationalist groups and parties. The city is increasingly curated as one with a 'history' of cosmopolitanism and social mixing and in which diversity has been associated directly with a 'global city' agenda. City authorities openly condemn forms of discrimination as running 
counter to the normative politics of a 'true' global city. This is despite (and in part because of) the presence of nationalist groups and an increasingly authoritarian national administration (see Fabula et al., 2014).

To summarise, we have shown that narratives of 'diversity' have become embedded into a complex milieu of historical and contemporary political processes and that in some cases these narratives are seen as an external 'imposition' on existing traditions and/or have acted as a focus for intense political debate and conflict. Simple narratives that position understandings of diversity and critical urban cosmopolitanism along geographical faultines, such as East-West or North-South, have limited utility as it is in cities in which interactions between broader and local trends insect under varying and specific conditions. These trends have become more acute with the onset of a perception of growing immigration, economic crisis, conflicting EU policies, and the rolling out of austerity agendas. Diversity discourses are thus embedded into highly contextualized political environments and used for a variety of ends, some of which reflect more celebratory uses of the term found in the 'pragmatic' city agendas but many of which are related to deepening economic crisis and/or the assertion of latent and manifest conflicts.

\section{Conclusions - Towards a Geography of Diversity}

This paper has drawn on the findings of a cross-national EU project to examine the geographies of diversity-related narratives and their influence on the governance and planning of cities. It has built on Delanty's call for a new methodological and analytical approach grounded in a critical urban cosmopolitanism, or a focus on the dynamic interactions between global and local processes in urban environments. The paper has shown that there is no one linear trajectory through which the term 'diversity' has taken on discursive and concrete fixes in urban social policy agendas across Europe. It has become one of a wider assemblage of terms and ideas (or ideologies) promoted by diversity regimes that influence thinking on what cities are as objects of intervention and what they should become. The adoption of a critical urban cosmopolitan approach sheds light on how policy fixes emerge and are forged through the relational interactions that result from: engagements between political cultures; historically-inscribed processes and practices; national and EU-wide policy prescriptions and narratives; dominant expectations of what a cosmopolitan, modern city 'should' consist of; and urban built environments and socioeconomic geographies. The case studies also highlight the processes of translation and (re)contextualisation of diversity that are taking place and how a term that appears to be relational and transcends political-national boundaries takes on a broad range of fixed and concrete forms.

It is important to recall that diversity agendas across Europe in the 1990s and 2000s emerged in a context of EU expansion, the widening and deepening of EU institutional roles and responsibilities, and (debt-financed) economic growth. In the period 2000-2008 these conditions fuelled what Rancière (2010) terms a 'Millennial politics' in which globalisation and post-national cosmopolitanism and its associated socio-cultural diversity, were presented as unchallengeable 'realities'. A post-national cosmopolitan future for much of Europe seemed assured. An approach grounded in critical cosmopolitanism, however, sheds light on the fragility of such processes and the reflexive and relational nature of changing governance 
arrangements and circumstances. The economic, political, and social certainties that characterised earlier periods have come under threat from multiple directions. The economic crisis precipitated by the financial crash of 2008 has created tensions across the EU and within nation states. The European 'social model' of capitalism, has been subject to new pressures with welfare settlements threatened by the processes of neo-liberal reform, economic restructuring, and growing social demands. This, as Delanty (2013) argues, is leading to an 'uncoupling of capitalism and democracy' (p.276) in new and more intense ways.

At the time of writing, and since the research was completed, new events in Europe have had an even more significant impact on the evolving politics of diversity within cities and nation-states. The so-called 'migrant crisis' and the influx of refugees in 2015-2016 exemplifies the ways in which political imaginations and policy-framings are still shaped by territorial concerns, rather than an acceptance of post-national cosmopolitan principles and responsibilities. Across Europe recent terror attacks have cast doubt on existing and future policies and encouraged growing support amongst political groups who oppose the growth of socio-cultural diversity. Simultaneously, in the UK the vote to Leave the EU in June 2006 represents a significant challenge to the authority of the EU and to economic and political elites. The outcome was, in part, based on political campaigns that openly presented growing diversity as a 'threat' to social cohesion and economic well-being (see Vote Leave, 2016). Referendum voting patterns show that Leave votes were higher in areas in which there had been proportionately large and recent relative increases in external migration (see The Economist, 2016b). This was mainly in smaller towns and rural areas, as opposed to cities in which the presence of diversity is long established.

As a consequence of these factors, it is increasingly clear that the political settlements that have enabled flows of people, investment, and goods to move across national borders have come under growing strain and may even go into reverse as new boundaries and restrictions are established. As noted in our examples, these tensions have existed for some time in cities, even those in which elite regimes promote celebratory narratives of diversity. But recent events have made the politics of diversity and immigration even more contentious, many of which are related to complex interactions between contemporary forms of divisive global capitalism (i.e. class politics), welfare reform, and nationalism, alongside and inter-twinned with growing sociocultural diversity. The paper has argued that an analytical approach and methodology grounded in critical urban cosmopolitanism represents a robust framework for explaining and describing the emerging geographies and the specific manifestations of these wider political trends in the politics of cities.

Given this, it may that the experiences of major cities in governing for diversity, as discussed in the paper, could act as the basis for the construction of a more critical territorial politics and the sites in which more globally-oriented forms of cosmopolitan politics and identity are given form and substance. Rather than being seen as a threat to the cosmopolitan politics of diversity, recent events may open up the opportunity for new governance fixes to emerge that are less focussed on divisive models of economic growth and give greater recognition to the social, economic, and political separations found in contemporary European cities and societies (Žižek, 2016). In focussing on reflexive and relational forms of critical urban cosmopolitanism future 
research agendas will need to explore the ways in which territorial forms of politics are being reconfigured in the wake of structural changes and highlight the conditions under which more reflexive and relational political projects, incorporating relational forms of cosmopolitanism and specific diversity fixes, might emerge and how.

\section{Acknowledgements}

The author would like to thank Vassilis Arapoglou and two anonymous referees for their thoughtful and systematic engagements with earlier drafts of the paper. Many thanks also to Claire Colomb, Jamie Kesten, Tatiana Moreira de Souza, Arne Saeys, Rikke Skovgaard Nielsen, Szabolcs Fabula, Zoltan Kovacs, Ewa Korcelli-Olejniczak, Katrin Grossman and other members of the DIVERCITIES consortium for their comments and encouragement, along with audiences at numerous conferences. Special thanks to the late Ronald van Kempen (1958-2016) without whom this paper would not have been possible. The project has received funding from the European Union's Seventh Framework Programme for research, technological development and demonstration under Grant Agreement No 319970 - DIVERCITIES. The views expressed in this publication are the sole responsibility of the author and do not necessarily reflect the views of the European Commission.

\section{References}

Ahmed, S. (2012) On Being Included, Duke University Press, Durham.

Andersen, H-T, Blach, V., Winther-Beckman, A. and Nielsen, R. (2014) Urban Policies on Diversity in Copenhagen, Denmark, European Commission, Brussels.

Arapoglou, V. (2012) Diversity, inequality and urban change, European Urban and Regional Studies, 19, 223-237.

Barberis, E., Kazepov, Y., Angelucci, A. (2014) Urban Policies on Diversity in Milan, Italy, European Commission, Brussels.

Beck, U. (2000) The Cosmopolitan Perspective: Sociology in the Second Age of Modernity, Blackwell, Oxford.

Beck, U. and Grandes, E. (2007) Cosmopolitan Europe, Cambridge University Press.

Beck, U., and Sznaider, N. (2006). Unpacking cosmopolitanism for the social sciences: a research agenda. The British Journal of Sociology, 57, 1-23.

Clarke, J. and Newman, J. (2012) 'Brave new world? Anglo-American challenges to universalism', in Anttonon, A., Häikiö, L. and Stefánsson, K. eds. (2012) Welfare State, Universalism and Diversity, Edward Elgar, London, pp.90-103.

Delanty, G. (2006) The cosmopolitan imagination: critical cosmopolitanism and social theory. The British Journal of Sociology, 57, pp. 25-47. 
Delanty, G. (2012) A cosmopolitan approach to the explanation of social change: social mechanisms, processes, modernity, Sociological Review, 60, 2, pp. 333-354.

Delanty, G. (2013) Formations of European Modernity - A Historical and Political Sociology of Europe, Palgrave, New York.

[The] Economist (2016a) 'How to manage the migrant crisis - and keep Europe from tearing itself apart', February $6^{\text {th }}$.

[The] Economist (2016b) 'Explaining the Brexit vote'. July 16 ${ }^{\text {th }}$, accessed at: http://www.economist.com/news/britain/21702228-areas-lots-migrants-voted-mainly-remainor-did-they-explaining-brexit-vote, 17 August 2016.

Escafré-Dublet, A., Lelévrier, C., and Tenfiche, S. (2014) Urban Policies on Diversity in Paris, France, European Commission, Brussels.

EUROPA (2015) United in Diversity - the EU Motto', accessed at: http://europa.eu/abouteu/basic-information/symbols/motto/index en.htm, 18 January 2016.

Eurostat (2016) Migration and migration population statistics, accessed at: http://epp.eurostat.ec.europa.eu/statistics explained/index.php/Migration and migrant popul ation statistics, 28 March 2016.

Fabula, S.., Horváth, D., and Kovács Z. (2014) Urban Policies on Diversity in Budapest, Hungary, European Commission, Brussels.

Fincher, R. and Iveson, K. (2008), Planning and Diversity in the City: Redistribution, Recognition and Encounter. Basingstoke: Palgrave Macmillan.

Goodhart, D. (2004) Too diverse? Prospect Magazine, Issue 95, accessed at: http://www.prospectmagazine.co.uk/features/too-diverse-david-goodhart-multiculturalismbritain-immigration-globalisation

Held, D. (2010) Cosmopolitanism - Ideas and Realities, Polity Press, Cambridge.

Holvino, E. and Kamp, A. (2009) Diversity management: Are we moving in the right direction? Reflections from both sides of the North Atlantic, Scandinavian Journal of Management, 25, 395-403.

Keith, M. (2005) After the Cosmopolitan? Multicultural Cities and the Future of Racism, Taylor and Francis, London.

Korcelli-Olejniczak, W., Bierzyński, A., Grochowski, M., and Węcławowicz, G. (2014) Urban Policies on Diversity in Warsaw, Poland, European Commission, Brussels.

Lädesmäki, T. and Wagener, A. (2015) Discourses on governing diversity in Europe: Critical analysis of the White Paper on Intercultural Dialogue, International Journal of Intercultural Relations, 44, 13-28. 
Lowe, K. (2013) Savage Continent - Europe in the Aftermath of World War II, Penguin, London.

Maloutas, T, Souliotis, N., Alexandri, G., Kandylis, G., Petrou, M. (2014) Urban policies on Diversity in Athens, Greece, European Commission, Brussels.

Martin, R. (2015) Rebalancing the spatial economy: The challenge for regional theory, Territory, Politics, Governance, DOI: 10.1080/21622671.2015.1064825.

Michaels, W. (2010) The Trouble with Diversity - How we Learned to Love Identity and Ignore Inequality, Holt Paperbacks, New York.

Nathan, M. (2015) After Florida: Towards an economics of diversity, European Urban and Regional Studies, 22: 3-19.

The New Statesman (2014) 'UKIP has won the European elections', accessed at: http://www.newstatesman.com/politics/2014/05/ukip-has-won-european-elections, 8 February 2015.

Plüss, L. and Schenkel, W. (2014) Urban Policies on Diversity in Zürich, Switzerland, European Commission, Brussels.

Raco, M., Kesten, J. and Colomb, C. (2014), Report 2f: Assessment of Urban Policies in London, UK. Brussels: European Commission.

Rancière, J. (2010) Chronicles of Consensual Times, Continuum Press, London.

Robinson, J. (2013) The urban now: Theorising cities beyond the new, European Journal of Cultural Studies, 16, 659-677.

Saeys, A., Albeda, Y., van Puymbroeck, N., Oosterlynck, S., Verschraegen, G., and Dierckx, D. (2014) Urban Policies on Diversity in Antwerp, Belgium, http://www.urbandivercities.eu/wpcontent/uploads/2013/05/Urban-Policies-on-Diversity-in-Antwerp.pdf, accessed 12 August 2015.

Saunders, D. (2010) Arrival Cities - How the Largest Migration in History is Re-Shaping Our World, Random House, London.

Sayer, A. (1997) Realism and Social Science, Sage, London.

Schiller, N. and Caglar, A. (2009) Towards a Comparative Theory of Locality in Migration Studies: Migrant Incorporation and City Scale, Journal of Ethnic and Migration Studies. 35, 177-202.

Syrett S. and Sepulveda L. (2012), Realising the diversity dividend: population diversity and urban economic development, Environment and Planning A, 43, 487-504.

Tasan-Kok, T., van Kempen, R., Raco, M., and G. Bolt (2013), Report 1 a Towards Hyper-Diversified European Cities: A Critical Literature Review. Brussels: European Commission.

Tersteeg, A. van Kempen, R. and Bolt, G. (2014) Urban Policies on Diversity in Rotterdam, The Netherlands, European Commission, Brussels. 
Tammaru, T., Leetmaa, K., Kährik, A., and Kamenik, K. (2014) Urban Policies on Diversity in Tallinn, Estonia, accessed at: https://www.urbandivercities.eu/wpcontent/uploads/2013/05/Urban-Policies-on-Diversity-in-Tallinn.pdf

Vote Leave (2016) 'EU membership stops us controlling who comes into our country, on what terms, and who can be removed. The system is out of control', accessed at: http://www.voteleavetakecontrol.org/briefing.html, 12 August 2016.

Warrell, H. and Pickford, J. (2013) Boris Johnson proposes 'London visa' to boost tech start-ups, Financial Times, September $8^{\text {th }}$, accessed at: http://www.ft.com/cms/s/0/62459d68-1701-11e3bced-00144feabdc0.html\#axzz3S6sFYgRQ

World Economic Forum (2015) 'The Diversity Dividend' accessed at: http://www.weforum.org/sessions/summary/diversity-dividend

Žižek, S. (2016) Against the Double Blackmail - Refugees, Terror and Other Troubles with Neighbours, Penguin, London. 
Figure 1: The Case Study Cities and Key Policy Narratives on Diversity

\begin{tabular}{|c|c|c|c|}
\hline City & Population & $\begin{array}{l}\% \text { Residents } \\
\text { with Non- } \\
\text { native } \\
\text { Ethnicity }\end{array}$ & Key Policy Narratives on Diversity \\
\hline Antwerp (Belgium) & 511,716 & 20 & $\begin{array}{l}\text { An early multicultural recognition of ethnocultural } \\
\text { include other forms of diversity but eventually shifte } \\
\text { recent years policy-makers have broadened the diver } \\
\text { attention away from ethnocultural minorities }{ }^{6} \text {. }\end{array}$ \\
\hline Athens (Greece) & 756,652 & 20 & $\begin{array}{l}\text { Dominant urban policies in Athens do not use exp } \\
\text { 'Diversity' appears as a term of public policy only } \\
\text { Union-funded projects and activities and reprodu } \\
\text { institutions in a rather ritualistic way'. }\end{array}$ \\
\hline Budapest (Hungary) & $1,725,000$ & 21.75 & $\begin{array}{l}\text { In general, the political environment and the insti } \\
\text { Hungary support diversity, but anti-diversity facto } \\
\text { making practices and in the resource allocation }{ }^{8} \text {. }\end{array}$ \\
\hline $\begin{array}{l}\text { Copenhagen } \\
\text { (Denmark) }\end{array}$ & 558,400 & 22.7 & $\begin{array}{l}\text { The dominant discourse in Copenhagen is pluralist } \\
\text { diversity and striving to create a city with room for } \\
\text { place as a strategy for achieving coherent and success } \\
\text { considerations being integrated into the everyday mar }\end{array}$ \\
\hline London (UK) & $8,173,900$ & 55 & $\begin{array}{l}\text { The term is highly contested and that in order to } \\
\text { presented in highly consensual, technical, and instrun } \\
\text { are very different views of what the term means an } \\
\text { alternative forms of urban development and urbanisn }\end{array}$ \\
\hline Milan (Italy) & $1,366,000$ & 19.1 & $\begin{array}{l}\text { There is no wide-scope, cross-sectoral, general and s } \\
\text { its promotion in the Italian policy and public agen } \\
\text { fragmented discourses concerning specific grou } \\
\text { institutional fragmentation }{ }^{11} \text {. }\end{array}$ \\
\hline Paris (France) & $2,274,880$ & 20 & $\begin{array}{l}\text { Diversity is not an official category of public policy } \\
\text { policies deal more or less explicitly with inequaliti } \\
\text { between citizens or neighbourhoods: Urban renewal }\end{array}$ \\
\hline $\begin{array}{l}\text { Rotterdam } \\
\text { (Netherlands) }\end{array}$ & 616,319 & 48 & $\begin{array}{l}\text { Rotterdam pays little attention to diversity, that di } \\
\text { matter of ethnicity, and that it is seen as a problem ra }\end{array}$ \\
\hline Tallinn (Estonia) & 430,106 & 47 & $\begin{array}{l}\text { Present policy discourses both at national and city } \\
\text { diversity, but the concept is vaguely elaborated in }\end{array}$ \\
\hline
\end{tabular}

\footnotetext{
${ }^{6}$ Saeys et al., (2014: p.4)

${ }^{7}$ Maloutas et al. (2014: p.4)

${ }^{8}$ Fabula et al. (2014: p.4).

${ }^{9}$ Andersen et al. (2014: p.4)

${ }^{10}$ Raco et al. (2014: p.4)

${ }^{11}$ Baberis et al. (2014: p.4)

${ }^{12}$ Escafré-Dublet et al. (2014: p.4)

${ }^{13}$ Tersteeg et al. (2014: p.4)
} 


\begin{tabular}{|l|l|l|l|}
\hline & & & $\begin{array}{l}\text { important dimension of diversity pertains to ethn } \\
\text { improve the social inclusion of minorities into Estoni }\end{array}$ \\
\hline Warsaw (Poland) & $1,708,500$ & 3.5 & $\begin{array}{l}\text { Warsaw is presented as a city hospitable for visitors a } \\
\text { equal treatment is promoted, while the actual foc } \\
\text { labour-market driven attraction of in-migrants from } \\
\text { Diversity-related policies can be divided into three } \\
\text { inclusion via social support and the active pro-diversi }\end{array}$ \\
\hline
\end{tabular}

${ }^{14}$ Tammaru et al. (2014: p.4)

${ }^{15}$ Korcelli-Olejniczak et al. (2014: p.4) 